FOREWORD: HERS H MANLANDIA 


\section{ROBIN HELD}

For thirty-five years, the San Francisco artist and filmmaker Lynn Hershman Leeson has explored the relationship of spectatorship to identity. ${ }^{1}$ A pioneer of "new media" art, she has introduced technological innovations in her work since the I970s; her achievements in this field include one of the first interactive artworks on videodisc, the forerunner of the DVD (Lorna, I983-84); the first artwork to use a touch-screen interface (Deep Contact, I984-89); one of the earliest networked robotic art installations (The Difference Engine \#3, 1995-98); and the Lynn Hershman Leeson (LHL) Process for Virtual Sets, first used in her feature film Conceiving Ada (I997). ${ }^{2}$

Until now, most exhibitions of Hershman Leeson's work have emphasized the artist's contributions to art using emerging technologies. Unfortunately, such a narrow focus does not fully reveal what is a rich and varied career that has explored consistent themes: the construction of identity in relation to vision, interactivity, the relationship between bodies and machines, and shifting ideas of the real and the virtual.

Hershmanlandia: The Art and Films of Lynn Hershman Leeson, organized by the Henry Art Gallery, University of Washington, is the first comprehensive United States survey of this important American artist's visual art and film. Premiering at the Henry from November 5 , 2005, to February 5, 2006, it is accompanied by the first critical monograph on the artist, The Art and Films of Lynn Hershman Leeson: Secret Agents, Private I, co-published by the Henry and University of California Press and featuring essays by art historians and curators as well as film historians and theorists. These two projects advance significantly the scholarship on Hershman Leeson's thirty-five years of creative output, giving scholars an opportunity to reassess Hershman Leeson's contributions to art and film history, feminist theory, emerging technologies, and the full range of late-twentieth- and early-twenty-first-century creative endeavor.

Hershmanlandia is the evocative term used by art critic and curator Pierre Restany to describe Hershman Leeson's “strategy of perpetual and infinite personality situations and 
fragmentations." ${ }^{3}$ Hershmanlandia, the exhibition, explores this strategy in both real and virtual space - a landscape populated by the multiple female personae and agents that have embodied Hershman Leeson's primary concepts and concerns, including Roberta Breitmore and her multiples, Lorna, CybeRoberta, Tillie, the Telerobotic Doll, Synthia Stock Ticker, Agent Ruby, and others. The exhibition presents the artist's constant and interrelated themes as seen in key works, including those in which these personae and agents appear. ${ }^{4}$ Operating as a series of feedback loops-earlier art reflecting on later incarnations, elaborations, or mutations - the exhibition makes visible Hershman Leeson's sustained focus on key subject matter over a variety of technological formats.

\section{ROBERTA BREITMORE AND TEKNOLUST}

In Hershmanlandia, viewers will encounter the renowned Roberta Breitmore project (I97478), presented for the first time in many years in its fullness as a performance, photo, and video work, juxtaposed with Hershman Leeson's latest film, Teknolust (2002). With Roberta Breitmore, the artist explored spectacle, surveillance, and spectatorship and their roles in constructing a sexed identity, albeit a very fragmented and shifting one. By inextricably entwining the bodyin-performance Roberta and the performance-as-documentation Roberta, Hershman Leeson also complicated any simple understanding of a performance as the "now" and its documentation as the "after now."

As Amelia Jones points out in her essay included in this volume, Roberta Breitmore was "a body to be seen and represented." ${ }^{6}$ In the early years of the performance, Hershman Leeson would construct Roberta by donning a costume, blonde wig, and makeup. Roberta's existence was officially substantiated by documents that included an apartment lease and an employment contract as well as her own driver's license (see p. I08), checking account, credit cards, and dental records. Therefore, Roberta's subjectivity was constructed not only by Hershman Leeson's performative role-playing, but also by Roberta's rent checks, the contents of her purse, and her personal photographs.

The Roberta Breitmore project invited "real-world" participation in September 1975 with the placement of an advertisement in the San Francisco Progress (see p. 28). The form of the ad was ambiguous; it could be construed as a listing for a roommate and/or as a personal ad. A post-office-box address was provided for responses. Over the length of the performance, Roberta received dozens of letters, all of which have been saved by Hershman Leeson as ar- 
tifacts. When Roberta agreed to meet someone, he (it was primarily, but not exclusively, men who responded) was immediately and unwittingly caught up in the artist's performance. Roberta would meet with each respondent three times at most, in order not to establish too close a relationship. Each meeting was recorded in surveillance images by various photographers (see p. I08). A tape recorder in Roberta's pocket produced an audiotape chronicle of her adventures.

Many of these photographic documents remained in their "original" form as evidence of Roberta's existence and her meetings with others, whom I will call, as a form of shorthand, "dates." Others were rephotographed by Hershman Leeson, who then drew on or collaged or painted over the resulting larger-scale prints, and added annotations to the margins or across the faces or bodies of Roberta and her date. Hershman Leeson continued to produce such documents even long after the body-in-performance Roberta ceased to exist. ${ }^{7}$ In 1975, by which time Roberta had had dates in Los Angeles and San Diego as well as in San Francisco, Hershman Leeson commissioned the artist Spain Rodriguez to create an eight-page comic strip of Roberta's adventures (see p. 29). His drawings were made from Roberta's photographic documents, both the surveillance photography and the reconstructed, elaborated collages.

Three years into the performance, Hershman Leeson expanded its exploration of fragmentation and multiplicity by hiring three additional women to perform as Roberta: Kristine Stiles, Michelle Larsen, and Helen Dannenberg. All three performers wore wigs and costumes identical to those worn by Hershman Leeson as Roberta (plate 5). Each had two home addresses and two jobs — one for Roberta and one for herself — and each corresponded with respondents to the advertisement and went on dates that were obsessively recorded in photographs and audiotapes. These photographs, like those of Lynn-Roberta, were then collaged and annotated. All four Robertas existed simultaneously for a short time, until Hershman Leeson ceased performing as Roberta, leaving three.

In 1978 the project was further expanded as part of an exhibition of Roberta artifacts entitled Lynn Hershman Is Not Roberta Breitmore / Roberta Breitmore Is Not Lynn Hershman, presented at the M. H. de Young Memorial Museum in San Francisco. A Roberta look-alike contest was held at the museum, attracting transvestites, gay men, women, young girls, and even a set of elderly female twins, all in blonde wigs, costumes, and makeup. As the contestants vied to win, Roberta was fractured and dispersed across their bodies. Photographs of contestants then entered the same process of rephotographing, painting, collaging, drawing, and annotating undergone by the other Roberta photographs. 
Half a year later, in a performance at the Palazzo dei Diamanti in Ferrara, Italy, above Lucrezia Borgia's tomb, the body-in-performance Roberta was laid to rest- "exorcised," in Hershman Leeson's term — when Michelle-Roberta set fire to Roberta's photographic image. Hershman Leeson participated in the performance as herself.

The Roberta Breitmore project is best known by way of the elaborated photographs, such as Roberta's Construction Chart \#2 (1975, plate 3), a photographic portrait that charts the cosmetic transformation of Lynn into Lynn-Roberta. Performance art, along with its documents and artifacts, troubles art history. It is especially challenging to the methodologies of the discipline and its foundational assumptions about artworks, artist-subjects, and viewers. What are the most relevant tools art historians might bring to bear on this proliferation of documentation that continues even after the body-in-performance has been "exorcised"? Do the photographs of Lynn-Roberta have a different status than the photographs of the other Robertas because they are a record of the body of the artist herself? Do the "original," unaltered surveillance photos have a different status than those collaged, painted, and elaborated by the artist? How does one talk about the multiple iterations of Roberta, including the versions performed by contestants in the look-alike contest? Performance art troubles the assumptions of art history in ways similar to those in which Roberta Breitmore troubles the notion of fixed identity, offering the discipline one of the better mirrors for exploring our current fragmented notion of human subjectivity.

The themes of provisional identity central to Roberta Breitmore were introduced to a broader audience with the feature-length film Teknolust, although here they were updated for a world where sex is no longer required for reproduction and where the once distinct boundaries between humans and machines are becoming increasingly permeable. This digital-age Frankenstein tale was written and directed by Hershman Leeson and shot by Hiro Narita on twentyfour-frames-per-second high-definition video. It stars Tilda Swinton playing four characters who are often seen onscreen at the same time.

In this science-fiction fantasy, the geneticist Rosetta Stone (looking like a dowdy version of Hershman Leeson) concocts a recipe that allows her to download her DNA into a computer program and create from it three clones, or "self-replicating automatons" (SRAs), each of whom is both sister and daughter to her. (This in itself is reminiscent of the three "clones" spawned by Lynn-Roberta in the Roberta Breitmore project.) Not quite machine and not quite human, these three SRAs — named Ruby, Olive, and Marinne after the red, green, and blue pixels used to create color on computer monitors - quickly begin to develop their own selfhood and pursue their own adventures. 
Raven-haired Ruby, always dressed in the brightest red, is the sexy, confident star of a Web chat room, "Ruby's E-Dream Portal," where she invites users to "emote from your remote" and beckons, "Let's e-dream together." Marinne, fiery maned and clothed in deep blue, discovers the world of cybershopping, stealing Rosetta's credit card information and intensely pursing her consumer pleasures on the geneticist's dime. She also develops an encrypted language as a way to rebel against Rosetta, allowing her to speak in secret to her sisters. Marinne becomes a skillful enough hacker to access Rosetta's code for cloning, the blueprint of the SRAs' identity. Olive, clad in emerald green, with her platinum-blonde hair covering half her face, is the most introverted and obedient and is seemingly the youngest of the sisters. She is often found reading psychology, philosophy, or history texts in bed with Marinne, who successfully draws her gullible sister into her wild schemes (plate 15 ).

Bred only with Rosetta's DNA, the SRAs need Y chromosomes to survive. How they acquire this “chromo" provides the film's central narrative. Ruby is the only clone Rosetta permits to leave the secret (virtual) lair and enter the real world. While Ruby sleeps, Rosetta downloads into her operating system seduction scenes from old films. Armed with some classic pick-up lines from these movies, Ruby ventures out at night to collect sperm for the injections vital to the continued existence of her and her siblings. Unfortunately, her singles-bar forays have unexpected consequences: the men she picks up develop a mysterious illness with bizarre symptoms, including impotence, the appearance of a bar code on their foreheads, and the crashing of their computer hard drives. Rosetta's employers hire private investigators to investigate the outbreak, calling it "bio-gender warfare." While Rosetta is distracted by these proceedings, all of her SRAs start making regular trips into the real world, having escapades together and alone, finding their way in a world of rapid change.

Teknolust deals provocatively with contemporary issues of fragmented identity in cyberspace, cloning, the future of artificial life, our shifting notions of the real and the virtual, and the changing relationship between bodies and machines. But ultimately it tells an individual story of love and reproduction: Ruby falls in love with Sandy, an incompetent print-shop employee. She is a copy; he makes copies, however ineptly. By the movie's end, Ruby and Sandy are happily anticipating the birth of their first child.

The relation of vision to identity and the fractured, multiple, and provisional nature of subjectivity are key to both Roberta Breitmore and Teknolust. Produced about thirty years apart, these two works together display Hershman Leeson's deeply considered and sustained investigation of these themes. 
For decades, Hershman Leeson has worked in both independent video/film and the visual arts, recently bringing these two streams together via the character Ruby, who appears not only in Teknolust but also as Agent Ruby, an artificially intelligent, animated Web agent. Existing in a multitude of platforms, including a Web site, a program downloadable onto a personal data assistant, and an interactive sculptural installation, Agent Ruby exemplifies current modes of interactivity and communication. By presenting both Teknolust and works featuring Agent Ruby, Hershmanlandia provides an opportunity to reevaluate Hershman Leeson's contributions to both art history and film history.

In the first incarnation of the project Agent Ruby (2002-), online users log onto "Ruby's E-Dream Portal" (featured in Teknolust), where Agent Ruby invites them to "ask me anything" while a seductive female voice on the pop sound track promises, "I can teach you to dream." Visitors type an introductory question to Ruby, Ruby types a response, and correspondence begins (see p. 93). In a more recent incarnation, Agent Ruby 2, a sculptural installation utilizing sophisticated animation techniques (exhibited in 2004), Ruby is capable of verbally responding to users' typed inquiries. A third version has recently been completed in which Ruby responds verbally to viewers' spoken inquiries through state-of-the-art voicerecognition technology.

\section{INTERACTIVITY}

Interactivity has remained a consistent focus for Hershman Leeson, whose earliest work predated the existence of the Internet. The Dante Hotel (1973-74), staged in a run-down residence hotel in San Francisco, represents one of the artist's first experiments in interactive and site-specific art. For this project, she rented a room, furnished the interior with the personal belongings of an invented tenant (plate 2), and then allowed visitors to explore these objects to flesh out the inhabitant's identity, past and present. Today, Hershman Leeson's explorations with interactivity occur both on and off the Internet. Web-based projects such as The Difference Engine \#3, which is linked to the film Conceiving Ada, and Agent Ruby, which is linked to the film Teknolust, deepen the artist's investigation of issues raised in The Dante Hotel: constructing alternate realities, destabilizing ingrained notions of identity, and expanding the possibilities of an artwork's outcome by opening it to viewer participation. In the context of the Internet, however, these ideas combine in new ways, underscoring the character of this mode of communication. 
For example, Agent Ruby has the ability to distinguish different users of "her" system and is furthermore shaped by these encounters. As with the fictional character Ruby in Teknolust, Agent Ruby's intelligence increases and becomes more flexible with each rendezvous, but these interactions now take place in the real world via the latest technology.

Many of the ideas embodied by Hershman Leeson's artwork have seemed ahead of their time. Perhaps for this reason, her contributions to art and film history have been underrecognized or misunderstood. The development of her work demonstrates her sustained attention to the construction of a viewer who is an active participant in the work of artengaging with and potentially altering it — rather than a passive voyeur. Beginning her long career in an art world focused on medium specificity, she continues in one accommodating a wide array of "post-studio" practices, including technological advances from analog to digital. During the same period, many important cross-disciplinary texts have theorized an increasingly complex relationship of humans to machines. ${ }^{?}$

\section{INFLUENCE}

The influence of Hershman Leeson's pioneering work in performance, video, film, and "new media" has been pervasive both in and out of an art context. Her impact can be seen in the free use of the diaristic by filmmakers Chantal Akerman, Su Friedrich, and Sadie Benning, among others. It is evident also in the art of "new media" practitioners as diverse as Victoria Vesna, Nell Tenhaaf, and Natalie Jeremijenko. Her influence on feminist, persona-based performance art can be traced in the work of artists as varied as Eleanor Antin, Colette, and Cindy Sherman. Finally, in the realm of popular culture, the independent feature-length comedy Desperately Seeking Susan (1985, dir. Susan Seidelman), starring Madonna, took its inspiration from Roberta Breitmore, and the independent thriller Lady Beware (1987, dir. Karen Arthur), starring Diane Lane, was spawned by Hershman Leeson's site-specific installation 25 Windows: A Portrait of Bonwit Teller (1976). More broadly, her technological innovations in digital and Webbased art have helped legitimize the "new media" of video, Web art, and works of artificial intelligence. The force of her personality and her personal courage have also helped push at the "glass ceiling" of the art and film worlds, gaining greater acceptance for all women creators of film, video, performance, and new media.

Hershman Leeson's art has been widely exhibited in group and solo museum exhibitions as well as in video and film festivals in the United States, Europe, and Asia. For her work in both film and the visual arts, Hershman Leeson has received numerous awards and accolades. 
In 1994 she was the first woman filmmaker to be honored with a retrospective at the San Francisco International Film Festival. The following year, she received the Siemens Medienkunstpreis, being cited as "the most influential woman working in new media." In I 998 she garnered the Flintridge Foundation Award for Lifetime Achievement for Visual Artists, followed by the prestigious Prix Ars Electronica in I999. Hershman Leeson's first feature film, Conceiving Ada, was screened at the 1998 Sundance Film Festival; the following year, the film earned her an IFP Independent Spirit Award nomination in the Someone to Watch category and the Outstanding Achievement in Drama award at the Festival of Electronic Cinema in Chiba, Japan. Teknolust premiered in the American Showcase section of the 2002 Sundance Film Festival and was awarded the Alfred P. Sloan Foundation Feature Film Prize in Science and Technology in 2002. ${ }^{10}$

Expressed prolifically in drawings, paintings, photographs, performances, robotic works, digital art, videos, films, interactive multimedia installations, and works of artificial intelligence, Hershman Leeson's project of self-analysis and self-mythification multiplies and refracts fictional identities to the point of exploding any stable notion of identity. Her work provides a remarkable artistic mirror for understanding our fragmented sense of subjectivity at the beginning of the twenty-first century.

\section{NOTES}

I. I refer to the artist as Lynn Hershman Leeson throughout my essay, although visual art and film audiences might know her best as Lynn Hershman. She added "Leeson" to her name following her I99I marriage to George Leeson, and this is how her film credits have subsequently appeared; however, her artworks are still often exhibited under the name Lynn Hershman. The Henry Art Gallery uses the name Lynn Hershman Leeson since the current exhibition and accompanying critical monograph bring together the full range of the artist's thirty-five-year output.

2. In this process, actors are filmed against a blue screen but are able to view monitors that show the scene in real time with slides, video, and graphics taking the place of the blue screen. E-mail correspondence with the artist, June 2003 .

3. Pierre Restany, "Hershmanlandia: Prière de toucher, Please Touch," in Chimaera monographie: Lynn Hershman (Hérimoncourt, France: Centre International de Création Vidéo, I992), p. 32; also on DVD.

4. In exhibiting her work, Hershman Leeson and her curators have most often divided her artistic production into two broad chronological categories: “B.C.” (before computers) and “A.D.” (after digital). This methodology, based on a teleology of technological progress, provides a very narrow lens through 
which to view Hershman Leeson's art and obscures the full range of ideas that have consistently informed her creative production. This B.C./A.D. construction also oversimplifies our understanding of media transition, suggesting instead only media revolution, a scenario of upheaval in which all previous "new medias" are swept aside.

5. See Amelia Jones, “'Presence’ in Absentia: Experiencing Performance as Documentation,” Art Journal 56, no. 4 (winter 1997), pp. I I-18.

6. See Amelia Jones, "Roberta Breitmore Lives On," in this volume, p. I05.

7. Artifacts documenting Roberta's officially corroborated identity have also continued to circulate long after the bodies-in-performance Roberta were retired. In 2002 I received as a gift a blank check signed by Roberta Breitmore.

8. See www.agentruby.com.

9. These include Norbert Wiener's writings on “cybernetics," Marshall McLuhan's on new technologies conceptualized as extensions of the human body, and Paul Virilio's on the "politics of speed," as well as Donna Haraway’s “cyborg manifesto,” Niklas Luhmann’s systems theory, and Lev Manovich's (more flexible but still McLuhanesque) articulation of a cut-and-paste model of communication. See, for example, Norbert Wiener, Cybernetics, or Control and Communication in the Animal and the Machine (Cambridge, Mass.: MIT Press, I96I); Marshall McLuhan, Understanding Media: The Extensions of Man (New York: Penguin Books, I964); Friedrich Kittler, Gramophone, Film, Typewriter (Berlin: Brinkmann and Bose, I986); Paul Virilio, Speed and Politics: An Essay on Dromology, trans. Mark Polizzotti (New York: Columbia University Press, 1986); Donna Haraway, Simians, Cyborgs and Women: The Reinvention of Nature (London: Free Association Press, 199I); and Lev Manovich, The Language of New Media (Cambridge, Mass.: MIT Press, 200I).

Io. Hershman Leeson's contributions are also included for mention in important historical surveys of feminist, new media, and performance art, including the survey of feminist art by Peggy Phelan in Helena Reckitt, ed., Art and Feminism (London: Phaidon, 200I); Michael Rush, New Media in Late TwentiethCentury Art (London: Thames and Hudson, 1999) and Video Art (London: Thames and Hudson, 2003); the survey of performance art by Amelia Jones in Tracey Warr, ed., The Artist's Body (London: Phaidon, 2002); and Steve Wilson, Information Arts: Intersections of Art, Science and Technology (Cambridge, Mass.: MIT Press, 2002). 
